\title{
Modern approaches to marine antifouling coatings
}

\author{
L.D. Chambers ${ }^{a, *}$, K.R. Stokes ${ }^{a, b}$, F.C. Walsh ${ }^{\text {a }}$, R.J.K. Wood ${ }^{a}$ \\ ${ }^{a}$ Surface Engineering and Tribology and Electrochemical Engineering Groups, School of Engineering Sciences, \\ University of Southampton, Southampton SO17 1BJ, UK \\ ${ }^{\mathrm{b}}$ Physical Sciences Department, Dstl Porton Down, Salisbury, SP4 0JQ, UK
}

Received 23 June 2006; accepted in revised form 21 August 2006

\begin{abstract}
Marine structures such as platforms, jetties and ship hulls are subject to diverse and severe biofouling. Methods for inhibiting both organic and inorganic growth on wetted substrates are varied but most antifouling systems take the form of protective coatings. Biofouling can negatively affect the hydrodynamics of a hull by increasing the required propulsive power and the fuel consumption. This paper reviews the development of antifouling coatings for the prevention of marine biological fouling. As a result of the 2001 International Maritime Organization (IMO) ban on tributyltin (TBT), replacement antifouling coatings have to be environmentally acceptable as well as maintain a long life. Tin-free self-polishing copolymer (SPC) and foul release technologies are current applications but many alternatives have been suggested. Modern approaches to environmentally effective antifouling systems and their performance are highlighted.
\end{abstract}

(C) 2006 Elsevier B.V. All rights reserved.

Keywords: Antifouling; Friction; Marine biofouling; Natural products

\section{Introduction}

Engineered structures such as ships and marine platforms, as well as offshore rigs and jetties, are under constant attack from the marine environment. These structures need to be protected from the influences of the key elements of the marine environment such as saltwater, biological attack and temperature fluctuations. Besides injectable biocides in closed systems, methods of protecting marine structures must be capable of expanding and contracting with the underlying surface, resist the ingress of water and control the diffusion of ions. Protective organic coatings can offer these functions [1] and consequently are largely used in the shipping industry to increase the working life of systems and improve its reliability. Paint coatings on ships are used for a wide range of functions such as corrosion resistance, ease of maintenance, appearance, non-slip surfaces on decking as well as the prevention of fouling on the hull by unwanted marine organisms.

The use of antifouling coatings for protection from the marine environment has a long history. By considering the historical and current approaches to antifouling systems, this

\footnotetext{
* Corresponding author. Tel.: +44 2380597667.

E-mail address: 1c701@soton.ac.uk (L.D. Chambers).
}

paper presents the use of modern approaches to the design of an environmentally acceptable, broad spectrum antifouling system for a large ship's hull.

The settlement and accumulation of marine organisms on an inanimate substrate can cause large penalties to engineered structures. In heat exchangers, biofouling can clog systems and on ship hulls it can increase the hydrodynamic drag, lower the manoeuvrability of the vessel and increase the fuel consumption. This leads to increased costs within the shipping industry through the increased use of manpower, fuel, material and dry docking time.

The process of biological fouling is often grouped in the literature into key growth stages which include an initial accumulation of adsorbed organics, the settlement and growth of pioneering bacteria creating a biofilm matrix and the subsequent succession of micro and macrofoulers (Fig. 1). A mature fouling coverage, which would include mortality and emigration of species, is not shown.

The sequence of biofouling is not predictable due to the exploitation of substrate niches by higher fouling organisms. Biofilm formation is often a precursor to subsequent fouling by macrofoulers. The succession of biofouling has been experimentally tested by removing initial algal layers resulting 


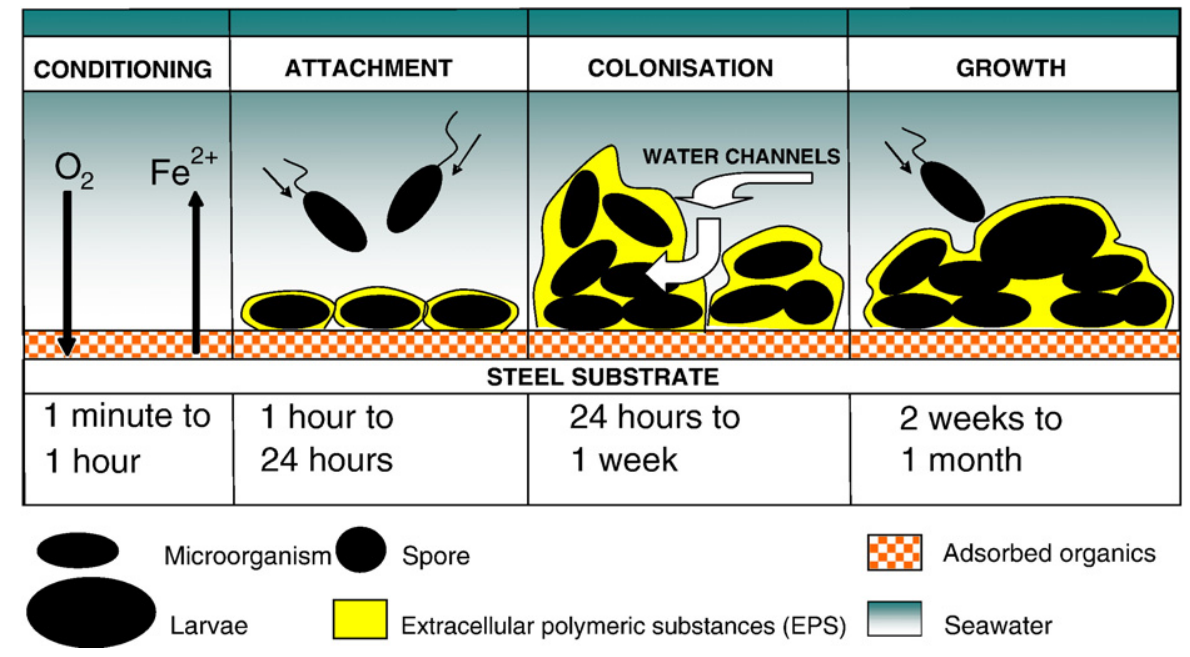

Fig. 1. Schematic of critical biofouling stages [8].

in limited further fouling [2]. The presence of a biofilm has been recorded to have a positive influence on the settlement of some algal zoospores [3], whereas Faimali et al. [4] recorded that an aging biofilm inhibited the settlement of barnacles. In general it is agreed that there is a sequence of events to biofouling and the first stage is usually taken to be the formation of a biofilm [5].

When a chemically inert substrate is immersed in seawater an almost immediate accumulation of organic carbon residues adsorb onto the wetted surface, composition of which depends on the ions, glycoproteins, humic and fulvic acids available in the liquid phase. The forces that promote the adsorption and conditioning of the surface include electrostatic interactions and Van der Waal's forces. Pioneering microorganisms can now attach to the surface forming a biofilm. Contact and colonisation between the microorganism and the surface is promoted by the movement of water through Brownian motion, sedimentation and convective transport, although organisms can also actively seek out substrates due to propulsion using flagella. Bacteria and other colonising microorganisms secrete extracellular polymeric substances (EPS) to envelope and anchor them to the substrate thereby altering the local surface chemistry which can stimulate further growth such as the recruitment and settlement of macroorganisms.

The biofilm generated is a mass of microorganisms and their EPS which creates a gel matrix (Fig. 1) providing enzymatic interaction, exchange of nutrients, protection against environmental stress [6] and an increased resistance to biocides [7].

Biofilms also interrupt the flow of ions and water to and from the substrate surface by acting as a diffusion barrier. The reduction of localised oxygen by cathodic reactions within the electrolyte can accelerate the corrosion of a metallic substrate by creating a differential aeration concentration cell.

A general review of biocorrosion is given by Videla [6], whilst more recently Beech and Sunner [9] have looked at biofilm influences on the corrosion of metals. It is important to control microbiological fouling as they can create a corrosive environment due to their life cycle and their ability to generate decomposition products. This type of corrosion is called micro- bially induced corrosion (MIC), an example of which is the production of sulphides from sulphate reducing bacteria which can cause the pitting corrosion of steel surfaces [10]. The control of MIC is a key outcome for the development of a successful coating which inhibits the attachment of biofouling.

The adhesion techniques employed by fouling organisms are diverse and can often be a two component process with both temporary and permanent adhesion. At the critical larval developmental stage of the barnacle, called the cyprid, a temporary adhesive is used while exploring the surface for a place to settle and permanently adhere [11]. Barnacles adhere by using a hydrophobic protein which crosslinks using cysteine residues [12]. There are many factors which can influence the settlement of barnacles, a key attribute being the presence of other barnacles (conspecific cues) through the remains of old exoskeletons or newly settled cyprids. In a similar manner, the common macroalgae Ulva sp., has a temporary and permanent attachment phase to its lifecycle. The motile zoospore stage can temporarily adhere while actively searching for a suitable substratum. When the optimal substrate is detected it transforms into the immotile, settled cell phase which can permanently anchor itself and germinate producing a new plant [13]. The hydrated adhesive strength of Ulva spore adhesive is $500 \mathrm{mN} \mathrm{m}^{-1}$ [13]. Mussels use byssus threads composed mainly of collagen but have, in contrast to barnacles, a hydrophilic polyphenolic adhesive protein which crosslinks in an oxidation-reduction reaction that occurs in the presence of an enzymatic catalyst [13]. Diatoms can attach by producing polysaccharide mucilages which can encapsulate cells forming pads, stalks or tubes [14].

The adhesion of species to a substrate is an important aspect of biofouling for if this process could be prevented, fouling could be controlled. Adhesion and settlement is also often a key stage in the life cycle of marine organisms, so the evolutionary pressure to colonise a surface is great. The driving force of adhesion can be considered as being made up of contributions from the interfacial tension between the organism and the substratum, organism and the liquid and between the substratum and the liquid. Methods of experimentally determining these 
interfacial energies through modelling have been investigated by Ista et al. [15] but they reported that more complex models are needed as certain estimations of organisms' attachment, such as Ulva zoospores, did not model quantitatively. A reason for this was stated that their model does not take surface charge into consideration and that electrostatic interactions may affect the attachment rates. Another contributing factor is that the colonisation of particular substrate features occurs such as rough surface areas to shelter from shear forces and/or flowing systems to maximise nutrient and oxygen concentrations.

\section{Fouling effects}

Antifouling systems are required wherever unwanted growth of biological organisms occurs. This is often in most saline aqueous phase environments; hence applications include medi$\mathrm{cal}$, freshwater and marine systems. Marine engineered systems have been categorised into seven key types of submerged structures of which ship hulls account for $24 \%$ of the total objects fouled [16]. A variety of materials can be used for ship hulls including steel, aluminium and composites such as glass reinforced polymer. The fouling of ship hulls is often prolific as vessels move between a diverse range of environments and remain constantly in the most productive region, the photic zone, of the water column. Although coatings are used for hull protection, they can fail due to the build up of inorganic salts [17], exopolymeric secretions, and the calcium carbonate skeletal structures that form the fouling organisms.

There are penalties associated with the unwanted colonisation of a hull surface by marine organisms [18], for example, hydrodynamics are negatively affected. A hull is subject to both form drag and skin friction drag as the vessel navigates through water. Biofouling affects the latter by increasing the average hull roughness and wall shear stress. The effects of antifouling coatings, such as self-polishing copolymer (SPC) and foul release coatings (FRCs), on the hydrodynamic boundary layer have been shown to have little influence on either its thickness or shape factor, although friction velocity was increased [19]. The negative effects of biofilm roughness on drag were studied by Shultz and Swain
[20] and the importance of this initial biological growth on the mean and turbulence profiles of marine vessels were highlighted.

Biofouling exploits ecological niches on a ship's hull, generating varying settlement densities. This can lead to manoeuvrability penalties in specific (e.g., propeller fouling) and nonspecific ways (e.g., water line fouling). A vessel's sound signature is also affected, by this degradation of a ship's performance, for both passive and active sonar systems [21].

\section{Historic antifouling methods}

The use of toxic antifoulants on ship hulls has been a historic method of controlling fouling but biocides such as lead, arsenic, mercury and their organic derivatives have been banned due to the environmental risks that they posed.

A revolutionary self-polishing copolymer technique employing a similar heavy metal toxic action to deter marine organisms was used with the antifoulant tributyltin (TBT) [23]. Antifouling systems that do not use heavy metals are the foul release coatings [24]. The use of organotins was eventually banned due to severe shellfish deformities and the bioaccumulation of tin in some ducks, seals and fish $[25,26]$, resulting in legislation that culminated in the global ban of tributyltin (Fig. 2); as reviewed by Champ [27] and Terlizzi et al. [28].

Thermoplastic, non-convertible surface organic coatings, which dry due to simple solvent evaporation, are today readily available although volatile organic compound (VOC) controls are limited in antifouling applications. Currently, the UK MOD VOC target levels, as documented in March 2005, are $400 \mathrm{~g} \mathrm{~L}^{-1}$ water free paint [29], but this is subject to review as the toxicity of modern tin-free antifouling systems is addressed. The development of antifouling systems has a long history but the last ten years has seen an increase in the focus on environmentally acceptable alternatives (Table 1).

\section{Modern antifouling alternatives}

Many traditional antifouling systems are 'paints', which is a comprehensive term covering a variety of materials: enamels,

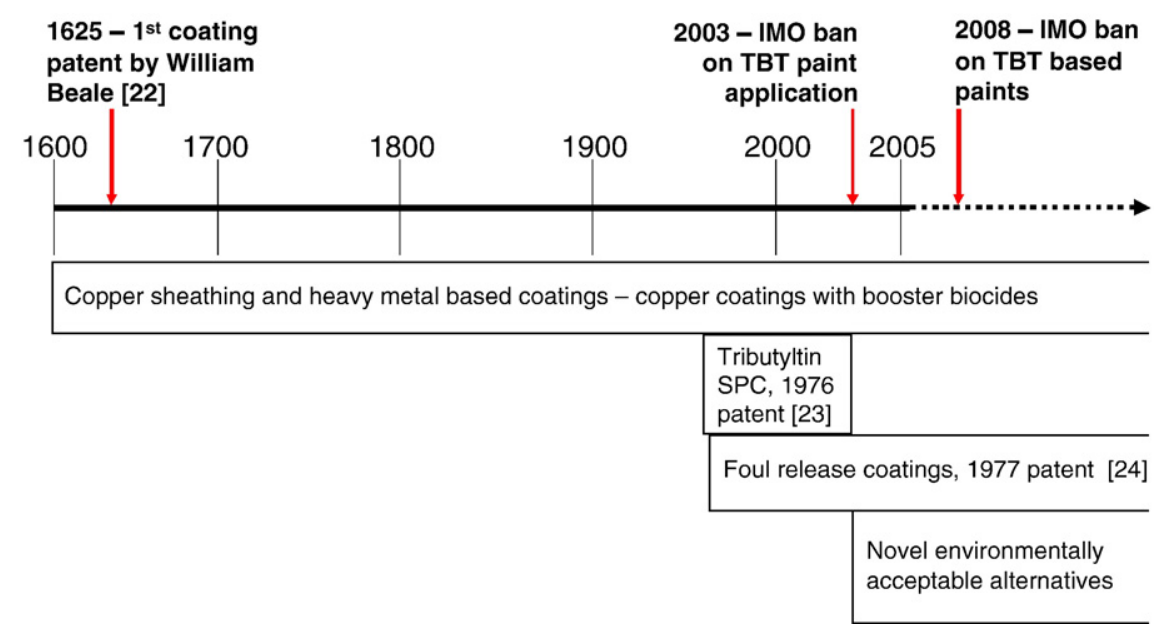

Fig. 2. Timeline for key antifouling generations [8]. 
Table 1

Major reviews on antifouling coatings over the last 50 years

\begin{tabular}{|c|c|c|c|c|}
\hline Author(s) [Ref] & Title & Theme & Year & $\begin{array}{l}\text { No. of } \\
\text { Refs }\end{array}$ \\
\hline $\begin{array}{l}\text { Woods Hole Oceanographic } \\
\text { Centre [22] }\end{array}$ & Marine fouling and its prevention & $\begin{array}{l}\text { Catalogue of fouling organisms and } \\
\text { historic antifouling technology }\end{array}$ & 1952 & 1091 \\
\hline Fischer, E. C. et al. [30] & $\begin{array}{l}\text { Technology for control of } \\
\text { marine biofouling - a review }\end{array}$ & Antifouling systems tried and tested & 1984 & 347 \\
\hline Wahl, M. [31] & $\begin{array}{l}\text { Marine epibiosis. I. Fouling and } \\
\text { antifouling: some basic aspects }\end{array}$ & Review of biological antifouling mechanisms & 1989 & 172 \\
\hline $\begin{array}{l}\text { Abarzua, S. and } \\
\text { Jakubowski, S. [32] }\end{array}$ & $\begin{array}{l}\text { Biotechnological investigation for the prevention } \\
\text { of biofouling. I. Biological and biochemical } \\
\text { principles for the prevention of biofouling }\end{array}$ & Biogenic agents to prevent biofouling & 1995 & 128 \\
\hline Clare, A. S. [33] & $\begin{array}{l}\text { Marine natural product antifoulants: } \\
\text { Status and potential }\end{array}$ & $\begin{array}{l}\text { Chemical structures, sources and mechanisms } \\
\text { of testing their efficiency }\end{array}$ & 1996 & 105 \\
\hline Swain, G. [34] & Redefining antifouling coatings & Promotion of novel methods & 1999 & 61 \\
\hline Champ, M. A. [27] & $\begin{array}{l}\text { A review of organotin regulatory strategies, } \\
\text { pending actions, related costs and benefits }\end{array}$ & Focus on organotins and the impending ban in 2003 & 2000 & 311 \\
\hline Terlizzi, A. et al. [28] & $\begin{array}{l}\text { Environmental impact of antifouling } \\
\text { technologies: state of the art and perspectives }\end{array}$ & $\begin{array}{l}\text { Influence of TBT on next generation of } \\
\text { antifouling technology }\end{array}$ & 2001 & 69 \\
\hline Lewis, J. [35] & $\begin{array}{l}\text { Hull fouling as a vector for the translocation } \\
\text { of marine organisms: report } 1 \text { and } 2\end{array}$ & $\begin{array}{l}\text { Review of TBT ban and the alternatives as well as } \\
\text { focusing on the environmental issue of species translocation }\end{array}$ & 2002 & 573 \\
\hline Omae, I. [36] & General aspects of tin-free antifouling paints & $\begin{array}{l}\text { Chemical properties, structures and functions of } \\
\text { tin-free alternatives; copper, booster biocides, natural products }\end{array}$ & 2003 & 165 \\
\hline Yebra, D. M. et al. [37] & $\begin{array}{l}\text { Antifouling technology - past, present and } \\
\text { future steps towards efficient and } \\
\text { environmentally friendly antifouling coatings }\end{array}$ & $\begin{array}{l}\text { Antifouling technology is reviewed with particular } \\
\text { emphasis on commercial products and the development } \\
\text { of an environmentally benign system }\end{array}$ & 2004 & 201 \\
\hline Railkin, A. I. [16] & $\begin{array}{l}\text { Marine biofouling colonization } \\
\text { processes and defenses }\end{array}$ & $\begin{array}{l}\text { Marine biological approach to the study of fouling, reports } \\
\text { on natural as well as artificial methods of antifouling }\end{array}$ & 2004 & 959 \\
\hline
\end{tabular}

lacquers, varnishes, undercoats, surfacers, primers, sealers, fillers, stoppers and many others [38]. Antifoulants are one of many additives usually incorporated within the topcoat paint of a marine protective coating system. The average theoretical spreading rates for commercially available antifouling systems for naval applications is considered to be around $6.2 \mathrm{~m}^{2} \mathrm{~L}^{-1}$ at $93 \mu \mathrm{m}$ dry film thickness, with the majority utilising two coat applications [29]. Most antifouling coatings are organic and consist of a primer and a topcoat both of which can include anticorrosive functions, however, the topcoat is often porous. Patenting biocontrol technologies and company protectivity has inhibited the flow of information regarding comparative values of efficiency. Since the initial phasing out of TBT from the antifouling industry in 2001 alternatives have been available $[36,39,40]$ including biocide-free antifouling coatings $[41,42]$.

In Table 2, the cost of alternatives can be seen to double in relation to the TBT based paints, a factor which is increased as alternative technologies are not reaching the current life of 4 to 5 years. To prolong the working life most antifouling coatings use a method of manufacturing the paint matrix composition to control the leaching of the antifoulants.

\subsection{Heavy metals}

The ban on TBT in 2003 created a gap in the market and research began into environmentally acceptable replacements (Table 1) as reviewed elsewhere $[28,36,37,40]$. In the interim, other metallic species, such as copper and zinc are in current use as substitutes and are delivered in a modified self-polishing copolymer delivery mechanism. The self-polishing copolymer (SPC) technique uses both hydrolysis and erosion to control the antifouling activity. Seawater ingress allows for the hydrolysation of the antifouling compound from the polymer backbone and the coatings solubility leaves the surface polished. This controlled dissolution of the surface of the coating allows for a longer lifetime.

There are two alternative key techniques for controlling the release of antifouling compounds from a coating by using either a soluble or insoluble matrix (Fig. 3).

Controlled dissolution of antifouling compounds is difficult and copper toxicity is under recent scrutiny [18]. Yebra et al. [47] have investigated the release rates of commercial rosin binders as effective methods to control this dissolution. Copper is found naturally in the marine environment at high concentrations and is relatively benign to humans although Environmental Protection Agency (EPA) regulations for drinking water stipulate a limit of $1000 \mu \mathrm{g} \mathrm{L}^{-1}$. Comparatively, concentrations as low as $5-25 \mu \mathrm{g} \mathrm{L}^{-1}$ can be lethal for marine invertebrates [48]. The biomagnification of sequestered copper species through the trophic levels, however, could potentially have an effect on the food industry. Heavy metals are often toxic to marine organisms and humans due to the partitioning of metabolic functions. The reticent use of heavy metals to control fouling in the marine environment due to the TBT ban and increased legislation on toxicity requirements is being replaced in favour of alternative approaches.

\subsection{Booster biocides approach}

As well as increased scepticism over the use of copper, an increased tolerance has been reported for a select group of 
Table 2

Performance comparison for the key antifouling systems used

\begin{tabular}{|c|c|c|c|c|c|}
\hline Antifouling system & Leaching rate & Lifetime & Erosion rate & Cost/US $\$ \mathrm{~m}^{-2}$ & Problems \\
\hline $\begin{array}{l}\text { (TBT) self-polishing } \\
\text { copolymer paints }\end{array}$ & $\begin{array}{l}\text { Chemical reaction through } \\
\text { hydrolysis. Reaction zone } \\
\text { of ablation } 5 \mu \mathrm{m} \text { deep. }\end{array}$ & $4-5$ years [28] & $\begin{array}{l}<3 \mu \mathrm{m} \text { month }^{-1}[40] . \\
\text { Polishing leads to smoothing, } \\
\text { reducing fuel consumption. }\end{array}$ & $\$ 680,884[35]$ & Banned 2008 [45] \\
\hline $\begin{array}{l}\text { (Tin-free) self-polishing } \\
\text { copolymers }\end{array}$ & $\begin{array}{l}\text { Chemical reaction through } \\
\text { hydrolysis of copper, zinc, } \\
\text { and silyl acrylate. }\end{array}$ & 5 years & $\begin{array}{l}\text { Polishing leads to smoothing, } \\
\text { reducing fuel consumption. }\end{array}$ & $\$ 1,382,670[35]$ & $\begin{array}{l}\text { Life time shorter then } \\
\text { TBT-based paint systems. } \\
\text { Increasing the overall cost of } \\
\text { ship maintenance. }\end{array}$ \\
\hline $\begin{array}{l}\text { (Tin-free) } \\
\text { conventional paint }\end{array}$ & $10 \mu \mathrm{g} \mathrm{cm}^{-2} \mathrm{~d}^{-1}[43]$ & $12-18$ months & N/A & N/A & $\begin{array}{l}\text { Hard non-polishing performance } \\
\text { leads to coating build up. } \\
\text { Performance only suitable for } \\
\text { low fouling environments [35]. }\end{array}$ \\
\hline $\begin{array}{l}\text { Control depletion } \\
\text { polymers (CDPs) - } \\
\text { copper paint }\end{array}$ & $\begin{array}{l}\text { Physical dissolution, } \\
\text { works by having a } \\
\text { soluble matrix. }\end{array}$ & 3 years & $\begin{array}{l}\text { Matrix erodes due } \\
\text { to dissolution of } \\
\text { coating binder. }\end{array}$ & $\$ 1,357,786[35]$ & $\begin{array}{l}\text { Biocide release not constant, } \\
\text { poor self-smoothing, little } \\
\text { activity during idle times, } \\
\text { higher costs due to necessity } \\
\text { of sealer coat on recoats [37]. } \\
\text { Slow drying time [35]. }\end{array}$ \\
\hline Foul release & $\begin{array}{l}\text { Low energy surface, } \\
\text { some use leached } \\
\text { silicone oils [44]. }\end{array}$ & $2-5$ years & N/A & N/A & $\begin{array}{l}\text { In-water cleaning difficult as } \\
\text { brushes may damage silicone, } \\
\text { foul release coatings are prone } \\
\text { to abrasion damage [46]. }\end{array}$ \\
\hline
\end{tabular}

macrophytes including the key fouling algal species Enteromorpha (now Ulva) [49]. As a result, booster biocides have been incorporated to increase the length and functionality of copper-based antifouling coating systems. Two of the key booster biocides (Irgarol 1051 and Diuron) have been regulated by the UK Health and Safety Executive [50,51] with Diuron banned from application and Irgarol restricted to application on vessels greater than $25 \mathrm{~m}$ in length. Terrestrial pesticides have also been adapted for marine antifouling systems but have increasingly had issues with their persistence and toxicity $[52,53]$. This approach is often too species specific or conversely too broad, influencing non-target organisms. The effectiveness of the copper-based coatings is restricted by the ability of the coatings to consistently leach the booster biocides. The concentrations of biocide released in free association paints (whether soluble or insoluble) requires better control [54]; also their persistence in marine sediments due to such mechanisms as incorporation within degraded paint particles needs continued monitoring [55]. The worldwide effects of the key booster biocides in antifouling coatings were reviewed by Konstantinou and Albanis [56]. The use of booster biocides provides an interim solution [40] in response to the demands for an effective antifouling strategy to replace TBT.

\subsection{Foul release approach}

Foul release coatings (FRCs) function due to a low surface energy which degrades an organism's ability to generate a strong interfacial bond with the surface. The smoothness of the coating at the molecular level allows for organisms to be dislodged once the vessel is moving beyond a critical velocity [44], i.e. typically 10-20 knots ship speed, depending upon the fouling community [37]. These non-stick surfaces aid removal of fouling through shear and tensile stresses as well as their own weight by lowering the thermodynamic work of adhesion [57].
A combination of the critical surface free energy (22-24 $\mathrm{mN}$ $\mathrm{m}^{-1}$ ) [34] and low elastic modulus allows the interface/joint between the organisms adhesive and the coating surface to fracture and fail [44]. The adhesion of a marine fouling organism to a wetted substrate creates two surfaces, the surface adhesive interface and the adhesive water interface [58]. As described earlier it is these interfacial tensions which control the organisms' ability to adhere.

There are two key types of FRCs, namely fluoropolymer and silicone based polymer coatings. The application thickness of silicone coatings is typically $150 \mu \mathrm{m}$ in comparison with $75 \mu \mathrm{m}$ for fluoropolymers [59]. The thickness of the coating allows for the coating modulus to be controlled. A thicker coating as seen with the silicone elastomers is more successful as it requires less

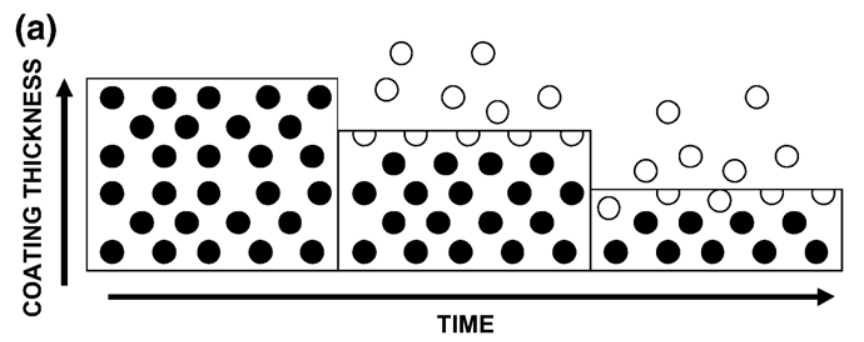

(b)

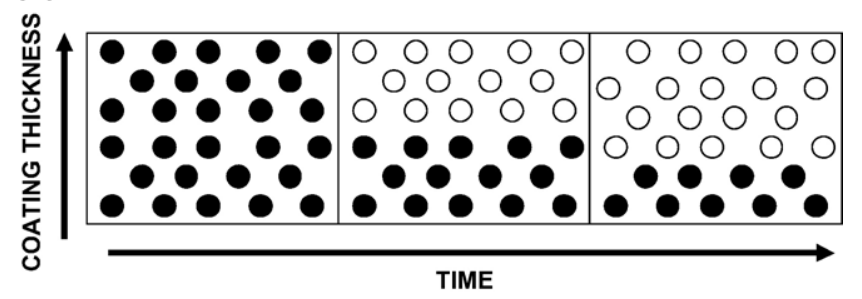

Fig. 3. Schematic of (a) soluble matrix biocide releasing coating and (b) insoluble biocide releasing coating. Antifoulant loaded, $\bigcirc$ depleted antifoulant. 


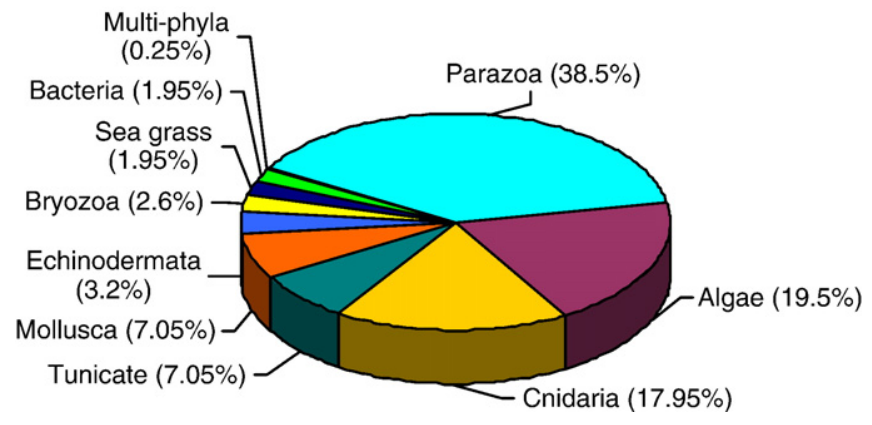

Fig. 4. Phyletic distribution of 160 reviewed marine species from which potential antifouling natural products have been extracted. Data has been compiled from various sources $[16,33,36,69,70]$.

energy to fracture the bond between the foulant/coating. Removal of the attached organism occurs through a peeling fracture mechanism as opposed to the shearing associated with the harder, thinner coatings of the fluoropolymer coatings.

Low form biofoulers like diatoms are especially tenacious and are difficult to remove from foul release coatings [60]. The implication of this is that the removal of diatomaceous slime from the non-stick coatings when the vessel is in transit is difficult. Using models of low form detachment, FRCs could be expected to remove 4-6 day old Ulva biofilms at operationally relevant ship velocities with greater than $60 \%$ removal of zoospores recorded at 17.7 knots [61].

The purely physical deterrent effects of these low energy coatings provide a unique approach to developing an environmentally acceptable alternative to biocide-based antifoulants. It offers a broad spectrum antifoulant without incurring the issues of biodegradation, legislative standards and fees necessary to register an active antifouling compound. This is an effective passive means of approaching the aggressive marine environment. However, the tenacity of biofilms increases the critical speed velocity needed to dislodge the foulers. As this approach does not tackle biofouling while the vessel is berthed dockside, biological communities are allowed to establish and macrofoulers can then be translocated biogeographically causing environmental issues of alien species transport. The negative effects of alien species on native biological communities include the competition for ecological niches eradicating indigenous species and generating issues for local biodiversity and aquaculture. There are also issues with the toxicity of the silicone oils in the dockyard and the use by some silicone based paints of the curing agent dibutyltin laureate [41]. This organotin catalyst may contain TBT and monobutyltin (MBT) compounds. FRCs are not a universal antifouling solution for ship hulls and require certain operational profiles to function efficiently. The penalty of increased fuel consumption until the vessel does 'release' the biological foulers has yet to be investigated thoroughly.

Shultz [62] compared the frictional resistance of an FRC with an SPC coating and determined that the low surface energy coatings had poorer performance and suffered larger increases in frictional resistance coefficient with static exposure time in the marine environment. Candries and Atlar [19] recorded an average increase in friction velocity of between $10-14 \%$ for foul release systems and between 13.4-23.5\% for tin-free SPC. Differences in coating application techniques can influence the surface roughness of coatings with an overall increase in the frictional resistance in roller applied FRCs than spray coated FRCs reported [19].

\subsection{A biomimetics approach}

The term 'biomimetics' deals with the bio-inspired based design rather than direct copying of natural biological functions. The term implies the use of the natural world as a model to base an engineering development or device upon [63] or as a 'bottom-up' strategy for hierarchical structures [64]. Application of a biomimetics approach for coatings include the control of deposition of inorganics such as silica and silver by biomolecules [64]; and an overview of how biomimetics is entering the molecular level with regard to functional coatings has been provided by Tamerler et al. [65].

The diverse mechanisms that marine organisms use to protect their own surfaces from fouling have been investigated $[31,66,67]$. Within the marine ecosystem, evolution has allowed for the development of certain antifouling properties. Marine organisms have both physical and chemical methods to protect themselves from the harmful process of biofouling $[31,67,68]$. Natural chemical defence methods have been of interest over the last two decades as chemical prospecting for pharmaceuticals has backed this type of research and exploration. A molecular approach to antifouling [17] has yielded a variety of potential compounds.

The key chemical antifouling mechanism of marine organisms occurs via the production of secondary metabolites (also known as natural products) which deter foulers. Natural products in chemical marine ecology are also termed secondary metabolites which are classified according to their metabolic pathway or biosynthesis.

The key phylum investigated as sources of natural antifouling products over the years (Fig. 4) include Porifera (sponges), Algae, Cnidaria (e.g. corals), Echinodermata (e.g. sea-urchins), Tunicates (e.g. sea-squirts), Bryozoa and bacteria. Of the 160

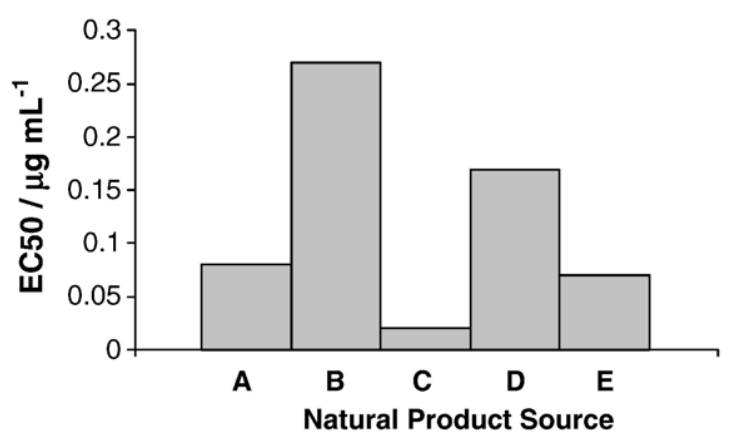
(A) Sponge (Acanthella cavernosa)
(B) Sponge (Reniera saral)
(C) Algae (Delisea pulchra)
(D) Mollousc (Phyllidia pustulosa)
(E) Tunicate(Eudistoma sp.)

Fig. 5. The effective concentrations (EC) of various natural products to inhibit $50 \%$ of the tested population of the barnacle B. amphitrite $[36,69,71]$. 
Table 3

Some key natural products that have been incorporated into paint systems

\begin{tabular}{|c|c|c|}
\hline Author, date [Ref] & Natural product source & Paint system used \\
\hline Burgess et al. [77] & $\begin{array}{l}\text { Bacteria: } \\
\text { Bacillus pumilus extract } \\
\text { Pseudomonas sp. extract } \\
\text { Bacillus licheniformis } \\
\text { extract } \\
\text { Bacillus subtilis extract }\end{array}$ & $\begin{array}{l}\text { Water based paint resin } \\
\text { Revacryl } 380 \text {, Harlaw } \\
\text { Chemical Company Ltd. }\end{array}$ \\
\hline Sjögren et al. [78] & $\begin{array}{l}\text { Marine Sponge } \\
\text { Bromocyclopeptides: } \\
\text { Barettin } \\
\text { 8,9-dihydrobarettin }\end{array}$ & $\begin{array}{l}\text { SPF SPC Lotréc } \\
\text { FabiEco SPC International } \\
\text { TF Solid paint/weak } \\
\text { SPC Lotréc } \\
\text { H2000 Solid paint/weak } \\
\text { SPC Lotréc }\end{array}$ \\
\hline Stupak et al. [79] & $\begin{array}{l}\text { Sodium benzoate } \\
\text { Chestnut tannin } \\
\text { Mimosa tannin } \\
\text { Quebracho tree tannin }\end{array}$ & $\begin{array}{l}\text { Soluble matrix tannate paint; } \\
\text { tannate, calcium carbonate, } \\
\text { rosin, phenolic varnish, } \\
\text { white spirit. Soluble matrix } \\
\text { sodium benzoate paint. }\end{array}$ \\
\hline
\end{tabular}

potential products collated from the literature $[16,33,36,69,70]$ $76 \%$ are from sponges, algae and cnidarians. As well as concentrating on individual organisms for inspiration, key trends in surface resistance to fouling have been exploited. Despite research into the use of antifouling natural products over the past 20 years, their incorporation into a functioning system to resist biofouling over a working timescale has yet to occur.

The performance of a natural product as an antifoulant can be initially tested by its effective concentration in a bioassay and the barnacle is a key fouling organism used. To date the halogenated furanone from the red seaweed Delisea pulchra has proved the most successful, with effective concentration levels for a $50 \%$ effect (EC50) being as low as $0.02 \mu \mathrm{g} \mathrm{mL}^{-1}$ (Fig. 5) [71].
When whole-cell marine extracts are processed as natural products the antifeedant chemicals are not separated from the antifouling allelochemicals and could elicit an antifouling effect from the compound that was not naturally used for that purpose. The literature emphasises the 'importance of showing that a compound must be released from, or at, the surface of an organism at an ecologically active concentration before a natural antifouling role can be proposed', see [67] as well as [33,71-73]. De Nys et al. [74] derived a method of determining the natural surface concentrations of marine algal products by solvent extraction. The use of biomimicry in the development of an antifouling system is a unique way to provide the inspiration for aqueous phase, ambient temperature solutions.

Methods of controlling the release of natural products was investigated by Price et al. [75] using microencapsulation technology. The recent incorporation of some natural products into engineered coatings is listed in Table 3. The incorporation of tannates has led to the development of a cupric tannate pigment with a narcotic antifouling activity. The combination of copper with the natural compound quebracho tannin has lowered the copper content in paint formulations by a factor of 40 when compared to that found in cuprous oxide paints [76]. Of the four marine bacterial compounds tested (Table 3), the Pseudomonas sp. extract exhibited a decrease in barnacle cyprid (12d) and algal settlement (6-7d) in comparison to the controls [77].

The physical defence mechanisms used by marine organisms to defend against biological coverage range from the spicules of an echinoderm to the mechanical breaching of cetaceans. On the macro scale, whales and dolphins have recently been studied for their antifouling skin properties $[80,81]$. The design of an antifouling coating with Sharklet AFTM topographies inspired by the placoids of a shark has had the capability of substantially reducing the settlement of the key fouling algae Ulva $[82,83]$. A study by Carman et al. [83]

Table 4

Microtexture effects on marine biofouling

\begin{tabular}{|c|c|c|c|c|}
\hline Coating & Organism & Dimensions & Effect & Author, date [Ref] \\
\hline $\begin{array}{l}\text { Polydimethylsiloxane } \\
\text { elastomers (PDMSe) }\end{array}$ & Ulva spores & $5 \mu \mathrm{m} \times 5 \mu \mathrm{m}$ channels & Preferential attachment & $\begin{array}{l}\text { Hoipkemeier-Wilson } \\
\text { et al. [88] }\end{array}$ \\
\hline PDMSe & Ulva spores & $\begin{array}{l}\text { Ribs with length } 4-16 \mu \mathrm{m}, 2 \mu \mathrm{m} \text { wide } \\
\text { and } 4 \mu \mathrm{m} \text { high, spaced } 2 \mu \mathrm{m} \text { apart }\end{array}$ & $\begin{array}{l}\text { Reduced settlement by } 86 \% \\
\text { relative to smooth PDMSe }\end{array}$ & Carman et al. [83] \\
\hline $\begin{array}{l}\text { Mould of crab } \\
\qquad(\text { C. pagurus }) \text { carapace }\end{array}$ & $\begin{array}{l}\text { Barnacle } \\
\text { (Balanus improvisus) }\end{array}$ & $\begin{array}{l}200 \mu \mathrm{m} \text { circular elevations and } \\
2-2.5 \mu \mathrm{m} \text { long spicules }\end{array}$ & Repelled for 1st 3 weeks & Bers and Wahl [84] \\
\hline- & Vorticella $\mathrm{sp}$ & - & Repelled in 3rd week & Bers and Wahl [84] \\
\hline $\begin{array}{l}\text { Mould of mussel } \\
\qquad(M . \text { edulis }) \text { shell }\end{array}$ & $\begin{array}{l}\text { Barnacle } \\
\text { (Balanus improvisus) }\end{array}$ & $1-1.5 \mu \mathrm{m}$ wide microripples in parallel & $\begin{array}{l}\text { Repelled for } 1 \text { st week, reversed } \\
\text { to preferential after } 3 \text { rd week }\end{array}$ & Bers and Wahl [84] \\
\hline $\begin{array}{l}\text { Mould of dogfish } \\
\qquad(\text { S. canicula }) \text { eggcase }\end{array}$ & $\begin{array}{l}\text { Cilliate } \\
\text { (Z. commune) }\end{array}$ & $\begin{array}{l}\text { Longitudinal ridges, } 30-50 \mu \mathrm{m} \text { wide, } \\
\text { parallel over distances } \sim 15-115 \mu \mathrm{m}\end{array}$ & Repelled in 2 nd week & Bers and Wahl [84] \\
\hline- & $\begin{array}{l}\text { Barnacle } \\
\text { (Balanus improvisus) }\end{array}$ & - & Repelled in 2nd week & Bers and Wahl [84] \\
\hline $\begin{array}{l}\text { Mould of echinoderm } \\
\qquad(\text { O. texturata })\end{array}$ & $\begin{array}{l}\text { Cilliate } \\
\text { (Z. commune) }\end{array}$ & $\begin{array}{l}10 \mu \mathrm{m} \text { diameter knobs spaced } \\
\text { about } 30 \mu \mathrm{m} \text { apart }\end{array}$ & Repelled in 3rd week & Bers and Wahl [84] \\
\hline $\begin{array}{l}\text { Medical grade Poly } \\
\text { (methyl methacrylate) }\end{array}$ & $\begin{array}{l}\text { Barnacle } \\
\text { (Balanus improvisus) }\end{array}$ & $\begin{array}{l}\text { Average roughness }\left(R_{\mathrm{a}}\right)=5-10 \mu \mathrm{m} \\
\text { Roughness height }=30-45 \mu \mathrm{m}\end{array}$ & $\begin{array}{l}92 \% \text { inhibition of barnacles } \\
\text { after } 1 \text { month in field trial }\end{array}$ & Berntsson et al. [86] \\
\hline $\begin{array}{l}\text { Mussel } \\
\qquad \text { (Mytilus galloprovincialis) shell }\end{array}$ & $\begin{array}{l}\text { Biofouling } \\
\text { community }\end{array}$ & $\begin{array}{l}1.5 \mu \mathrm{m} \text { high ridges at distances } \\
\text { of } 1-2 \mu \mathrm{m}\end{array}$ & $\begin{array}{l}<10 \% \text { biofouling after } \\
14 \text { weeks in field trial }\end{array}$ & Scardino et al. [85] \\
\hline $\begin{array}{l}\text { Pilot whale skin } \\
\qquad \text { (Globicephala melas) }\end{array}$ & & $\begin{array}{l}0.1-1.2 \mu \mathrm{m}^{2} \text { pores } \\
\text { enclosed by nanoridges }\end{array}$ & Proposed antifouling effect & Baum et al. [80] \\
\hline Lotus leaf & & $1-5 \mu \mathrm{m}$ relief structures & Self cleaning ability & Barthlott and Neinhus [94] \\
\hline
\end{tabular}


Table 5

Further antifouling coating alternatives

\begin{tabular}{|c|c|c|}
\hline AF system & Reference or company & Performance \\
\hline $\begin{array}{l}\text { Glass flake } \\
\text { lining technology }\end{array}$ & $\begin{array}{l}\text { Subsea Industries' } \\
\text { Ecospeed }\end{array}$ & $\begin{array}{l}\text { Good for ice breakers and } \\
\text { other abrasive uses. }\end{array}$ \\
\hline $\begin{array}{l}\text { Electrochemical } \\
\text { control }\end{array}$ & Matsunaga and Lim [96] & $\begin{array}{l}\text { Main application is in } \\
\text { closed systems. }\end{array}$ \\
\hline Fibre flocking & Phillippi et al. [97] & $\begin{array}{l}\text { Long and complex } \\
\text { application process. }\end{array}$ \\
\hline $\begin{array}{l}\text { Commercial } \\
\text { enzymes }\end{array}$ & Pettitt et al. [98] & Is not broad spectrum. \\
\hline Electrical fields & Leya et al. [99] & $\begin{array}{l}\text { Issues with a sound signature } \\
\text { for military applications. } \\
\text { Expensive to install for } \\
\text { large hulls. }\end{array}$ \\
\hline
\end{tabular}

looked at the effects of polydimethylsiloxane elastomers with tailored architecture on the surfaces wettability and resistance to bioadhesion. There is an increased interest in natural microtopography $[80,84,85]$ and synthetic microtextured surfaces $[15,86-88]$ with antifouling properties. The sensitivity of some organisms' settlement to the size and periodicity of surface topography has also led to the synthetic development of such architectural coatings. Surface properties of shells both physically and chemically are under further investigation $[85,89]$. The effective range of micro relief shown to have an antifouling effect can be seen in Table 4 .

PEGylation is the immobilisation of polyethylene glycol (PEG) on to a surface. The recent development of 'PEGylation' using mussel adhesive proteins has led to the suggestion that they may be used to achieve high densities of protein resistant polymers on surfaces [90]. Lewis et al. (2000) [91] have examined the development of cell biomembrane biomimicry and the resulting phosphorylcholine (PC) - based polymers have been investigated to establish their potential to resist fouling. Navarro-Villoslada et al. [92] also used PC-based polymers to successfully protect luminescent oxygen sensors from biofoul-

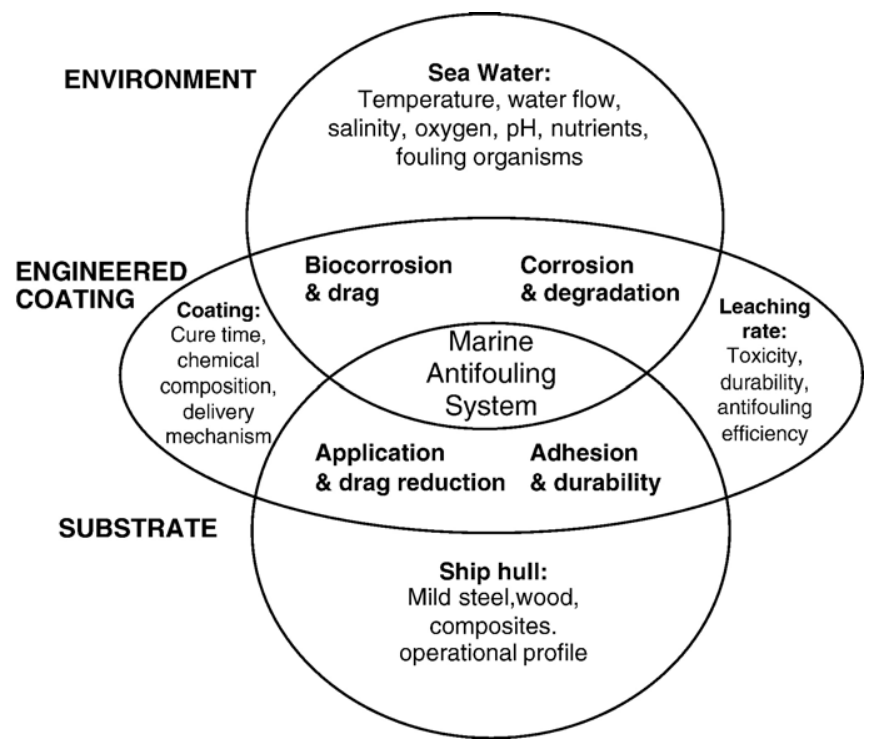

Fig. 6. Key interactive parameters affecting an antifouling coating system [8]. ing. A $70 \%$ decrease in the surface concentration of adhered bacteria under $2.5 \mathrm{~mL} \mathrm{~min}^{-1}$ flow was reported when compared with an uncoated control. The surface free energy [93], polar properties and the tailored micro-architecture [87] of materials have also been investigated with the aim of developing novel antifouling surfaces.

A comprehensive review of the uses of systematic systems to aid the transfer of information and technology from biology to engineering has been provided by Vincent and Mann [95]. The key system used by those wishing to engineer and functionalise a natural process is Teoriya Resheniya Izobreatatelskikh Zadatch (TRIZ), which is the theory of inventive problem solving, also termed controlled creativity or systematic innovation. It is composed of a database of inventive principles based on the typical approaches of over 400,000 patents. It can be used as a tool to systematically control the development of a functioning product. The advantages of this method are that it highlights trends and helps to resolve technical contradictions. A drawback is that in the biological world the inventive principles on how they function are very complex and difficult to rationalise.

\section{Further antifouling coatings}

A wealth of alternatives have been initially investigated for various marine applications to replace the use of TBT (Table 5). Further alternatives to the approaches of SPC, FRC, control depletion polymer, natural products and surface micro-architectures can be seen in Table 5 .

The process of surface flocking is where electrostatically charged fibres are adhered to a coating perpendicular to the surface and is currently undergoing trials as an antifoulant mechanism. The fibres can be made of polyester, polyamide, nylon or polyacryl [41]. Using nylon fibres on a polyvinylchloride plastic sheet a decrease in green algae and barnacles was recorded for a 6 month field trial [97]. Other non-toxic coatings have been developed such as the two coat systems of basecoat polybutadiene or urethane and a topcoat of silicone or hydrocarbon [100]. All five two coat systems were fouled by slime and algae but were resistant to fouling by barnacles and bryozoans in field trials $6-12$ months in length. Alternative surfaces that resist bioadhesion such as short chain PEG have been investigated [101] as well as alternative surface architecture to resist protein adsorption [102].

Table 6

Requirements for an optimal antifouling coating

\begin{tabular}{ll}
\hline Must be: & Must not be: \\
\hline Anticorrosive & Toxic to the environment \\
Antifouling & Persistent in the environment \\
Environmentally acceptable & Expensive \\
Economically viable & Chemically unstable \\
Long life & A target for non-specific species \\
Compatible with underlying system & \\
$\begin{array}{l}\text { Resistant to abrasion/biodegradation/erosion } \\
\text { Capable of protecting regardless of } \\
\quad \text { operational profile }\end{array}$ & \\
Smooth & \\
\hline
\end{tabular}




\section{Antifouling systems - universal approaches}

There are three key aspects (Fig. 6) that need attention, the engineered protective coating bounded on either side by the substrate and the environment, both of which have unique properties that will affect coating integrity and effectiveness.

The requirements needed for an optimal antifouling coating are outlined in Table 6 and additional factors that need to be considered include its life cycle parameters and measurable effectiveness [103] which incorporate toughness, erosion and release of the antifouling compound [53,104]. An innovative way to achieve the latter is to use microencapsulation techniques as this allows a controlled release, permitting the worklife of the protective coating to be increased. Price et al. [75] investigated this approach through the use of dry microcylinder powder with some success.

A method used to evaluate the antifouling capability of a prospective deterrent is often through settlement assays, where key macrofoulers such as barnacles and seaweed are used to test for percentage coverage and removal, mussel attachment has also been used as an indication of success [105]. Microfoulers such as biofilm formation and bacteria counts can be quantified using luminescent bacteria test [41] and nucleic acid stains [96]. Direct comparisons of the performance data of antifouling coatings are complicated as a result of inconsistencies with the materials and methods used to measure new compounds and surface coating properties.

\section{Summary and outlook}

1. This article has reviewed over 100 papers and 10 major reviews. It has considered modern approaches to achieve broad spectrum, environmentally acceptable antifouling performance, particularly for ships hulls. The degree of success of an antifouling coating must be determined with respect to its application. Engineering paints accounted for $29 \%$ of the UK coating technology sectors market valued at $£ 1548$ million in 2005 [106]. Unfortunately, operational profiles vary; hence the application of one universal coating to ship hulls is unlikely and specific coatings designed for the particular needs of certain exposure and operational profiles may need to be targeted individually. This, however, is no different to existing antifouling systems as these also do not cater for all operational profiles. The IMO legislation and the increased legislation of local and regional pesticide control authorities are the largest driving forces for the design and implementation of non-toxic antifouling coatings.

2. Heavy metals and booster biocides such as Irgarol 1051 and Diuron are not an environmentally acceptable alternative due to increased concerns over their toxicity, but do offer cost benefits. FRCs are broad spectrum with regards to targeting fouling organisms but they do not resist fouling while the vessel is dockside, which increases the frictional resistance of the coatings and the ability to translocate alien species. FRCs are effective for specific applications and also critically avoid the need for a registered antifouling chemical, making its production and use in the future economically viable.
3. A biomimetic approach provides a method incorporating nature's antifouling solutions to solve its own problems. The limitations of this approach are the practical application of a design solution which successfully mimics an ecologically significant antifouling effect found in the marine natural world. A natural antifouling compound that has both broad spectrum activity and species specific antifouling performance is potentially difficult to isolate from one organism. Also, as biological foulers have a diverse size range and preferential surface attachment criteria one single pattern of tailored micro-architecture will not be effective [88]. A synergistic and more realistic biomimetic approach could be found through the combination of an organism's chemical and physical antifouling attributes and may even 'more accurately reflect antifouling strategies adopted by organisms in nature' (Clare et al. [17]). Present modern methods of biofouling control are effective alternatives to the TBT antifouling coatings, but not yet their equal. Therefore, research into varied approaches to the design and implementation of antifouling coating technology must continue.

\section{Acknowledgments}

(C) Crown copyright 2006 Dstl. Funding from the Defence Science and Technology Laboratory (Dstl) is gratefully acknowledged. Part of the information in this paper was presented at the World Maritime Technology Conference 2006.

\section{Appendix A. Biological terms}

\begin{tabular}{ll}
\hline Biological term & Definition \\
\hline Flagella & Projecting propulsive organelles. \\
Byssus & Tuft of silky filaments used by mussels to \\
adhere to objects. & Layers of the ocean reached by sufficient \\
Photic & sunlight to allow plant growth. \\
Spicules & Spines characteristic of the surface of \\
& sea_urchins \\
Furanone & Five_membered ring lactone natural \\
& product with the ability to disrupt the \\
& acylated homoserine lactone regulatory \\
& systems in organisms. \\
Chemicals produced by a species to inhibit \\
the growth of different species. \\
Tanning substance from a family of \\
hardwood evergreen trees.
\end{tabular}

\section{References}

[1] C.G. Munger, Corrosion Prevention by Protective Coatings, National Association of Corrosion Engineers, Houston, TX, 1984.

[2] M.J. Dring, The Biology of Marine Plants, Edward Arnold (Publishers) Limited, London, 1982.

[3] P. Patel, M.E. Callow, I. Joint, J.A. Callow, Environ. Microbiol. 5 (2003) 338.

[4] M. Faimali, F. Garaventa, A. Terlizzi, M. Chiantore, R. Cattaneo-Vietti, J. Exp. Mar. Biol. Ecol. 306 (2004) 37.

[5] J.W. Costerton, Int. J. Antimicrob. Agents 11 (1999) 217.

[6] H.A. Videla, Manual of Biocorrosion, CRC Press, Inc., Boca Raton, Florida, US, 1996. 
[7] L.H.G. Morton, D.L.A. Greenway, C.C. Gaylarde, S.B. Surman, Int Biodeterior. Biodegrad. 41 (1998) 247.

[8] L.D. Chambers, F.C. Walsh, R.J.K. Wood, K.R. Stokes, World Maritime Technology Conference, ICMES Proceedings, The Institute of Marine Engineering, Science and Technology, March 2006.

[9] I.B. Beech, J. Sunner, Curr. Opin. Biotechnol. 15 (2004) 181.

[10] R.G.J. Edyvean, Mar. Technol. Soc. J. 24 (1990) 5.

[11] L. Khandeparker, A.C. Anil, Int. J. Adhes. Adhes. (in press).

[12] M.J. Naldrett, J. Mar. Biol. Assoc. U.K. 73 (1993) 689.

[13] M.E. Callow, J.A. Callow, Biologist 49 (2002) 1.

[14] M.E. Callow, Chem. Ind. (Lond) 5 (1990) 123.

[15] L.K. Ista, M.E. Callow, J.A. Finlay, S.E. Coleman, A.C. Nolasco, R.H. Simons, J.A. Callow, G.P. Lopez, Appl. Environ. Microbiol. 70 (2004) 4151.

[16] A.I. Railkin, Marine Biofouling Colonization Processes and Defenses, CRC Press LLC, 2004.

[17] A.S. Clare, D. Rittschof, D.J. Gerhart, J.S. Maki, Invertebr. Reprod. Dev. 22 (1992) 67

[18] R.L. Townsin, Biofouling 19 (2003) 9 (Supplement).

[19] M. Candries, M. Atlar, J. Fluids Eng. 127 (2005) 219

[20] M.P. Schultz, G.W. Swain, Biofouling 15 (2000) 129.

[21] E. C. Haderlie, in: J. D. Costlow, R. C. Tipper (Eds.), Marine Biodeterioration: An Interdisciplinary Study, Naval Institute Press, MD, USA, London E. and F.N. SPON, 1984.

[22] Woods Hole Oceanographic Institution, Marine Fouling and its Prevention, US Naval Institute Press, Annapolis, MD, 1952.

[23] A. Milne, G. Hails, GB Patent (1976), International Paint, 1,457,590.

[24] A. Milne, G. Hails, GB Patent (1977) International Paint, 1,470,465.

[25] J. Strand, J.A. Jacobsen, Sci. Total Environ. 350 (2005) 72.

[26] S.M. Evans, T. Leksono, P.D. McKinnell, Mar. Pollut. Bull. 30 (1995) 14.

[27] M.A. Champ, Sci. Total Environ. 258 (2000) 21.

[28] A. Terlizzi, S. Fraschetti, P. Gianguzza, M. Faimali, F. Boero, Aquat. Conserv. Mar. Freshw. Ecosyst. 11 (2001) 311.

[29] STMGT Sea Technology Group, Warpaint, Issue 20 (2005).

[30] E. C. Fischer, V. J. Castelli, S. D. Rodgers, H. R. Bleile, in: J. D. Costlow, R. C. Tipper (Eds.), Marine Biodeterioration: An Interdisciplinary Study, Naval Institute Press, MD, USA, London E. and F.N. SPON, 1984.

[31] M. Wahl, Mar. Ecol., Prog. Ser. 58 (1989) 175.

[32] S. Abarzua, S. Jacobowski, Mar. Ecol., Prog. Ser. 123 (1995) 301.

[33] A.S. Clare, Biofouling 9 (1996) 211.

[34] G. Swain, J. Prot. Coat. Linings 16 (1999) 26.

[35] J. Lewis, Hull fouling as a vector for the translocation of marine organisms: Report 1 and 2, Dept. of Agriculture, Fisheries and Forestry-Australia, Marine Science and Ecology Pty. Ltd. Commonwealth of Australia, 2002.

[36] I. Omae, Chem. Rev. 103 (2003) 3431.

[37] D.M. Yebra, S. Kiil, K. Dam-Johansen, Prog. Org. Coat. 50 (2004) 75.

[38] G.P.A. Turner, Introduction to Paint Chemistry, Science Paperbacks, Chapman and Hall Ltd, London, 1967.

[39] B. Watermann, Alternative Antifouling Techniques: Present and Future, Report, LimnoMar, Hamburg, Germany, May 1999.

[40] I. Omae, Appl. Organomet. Chem. 17 (2003) 81.

[41] B. Watermann, B. Daehne, S. Sievers, R. Dannenberg, J.C. Overbeke, J.W. Klijnstra, O. Heemken, Chemosphere 60 (2005) 1530.

[42] B. Watermann, B. Daehne, M. Wiegemann, M. Lindeskog, S. Sievers, Volume III Performance of Biocide-Free Antifouling Paints, LimnoMar, Hamburg, Norderney, 2003.

[43] G. Swain, Oceans 86 Conference Record, IEEE/MTS, Washington, D.C., 1986, p. 221.

[44] R.F. Brady Jr., I.L. Singer, Biofouling 15 (2000) 73.

[45] IMO, International Convention on the Control of Harmful Anti-fouling Systems on Ships AFS/CONF/26, vol. 18, October 2001.

[46] J.A. Lewis, Proceedings: National Shipping Industry Conference, Sydney, NSW, Australian Maritime Safety Authority, Canberra, March 2001.

[47] D.M. Yebra, S. Kiil, K. Dam-Johansen, C. Weinell, Prog. Org. Coat. 53 (2005) 256.

[48] P.V. Hodson, U. Borgmann, H. Shear, in: J.O. Nriagu (Ed.), Copper in the Environment Part II: Health Effects, Wiley-Interscience, New York, 1979, p. 307.
[49] N. Voulvoulis, M.D. Scrimshaw, J.N. Lester, Chemosphere 47 (2002) 789.

[50] J.C. Chesworth, M.E. Donkin, M.T. Brown, Aquat. Toxicol. 66 (2004) 293.

[51] S.J. Lambert, K.V. Thomas, A.J. Davy, Chemosphere 63 (2006) 734

[52] K.V. Thomas, T.W. Fileman, J.W. Readman, M.J. Waldock, Mar. Pollut. Bull. 42 (2001) 677.

[53] R.A. Devilla, M.T. Brown, M. Donkin, G.A. Tarran, J. Aiken, J.W. Readman, Mar. Ecol., Prog. Ser. 286 (2005) 1.

[54] M. Thouvenin, J.-J. Peron, V. Langlois, P. Guerin, J.-Y. Langlois, K. Vallee-Rehel, Prog. Org. Coat. 44 (2002) 85.

[55] K.V. Thomas, M. McHugh, M. Hilton, M. Waldock, Environ. Pollut. 123 (2003) 153.

[56] I.K. Konstantinou, T.A. Albanis, Environ. Int. 30 (2004) 235.

[57] M. Berglin, N. Lönn, P. Gatenholm, Biofouling 19 (2003) 63 (Supplement).

[58] R.F. Brady Jr., Prog. Org. Coat. 35 (1999) 31.

[59] R.F. Brady Jr., Prog. Org. Coat. 43 (2001) 188.

[60] C. Anderson, M. Atlar, M. Callow, M. Candries, A. Milne, R.L. Townsin, J. Mar. Design Operations B4 (2003) 11.

[61] M.P. Schultz, J.A. Finlay, M.E. Callow, J.A. Callow, Biofouling 19 (2003) 17 (Supplement).

[62] M.P. Schultz, J. Fluids Eng. 126 (2004) 1039.

[63] D. De Rossi, A. Ahluwalia, 1st Annual International IEEE-EMBS Special Topic Conference on Microtechnologies in Medicine and Biology, Lyon, France, IEEE, 2000.

[64] R.R. Naik, L.L. Brott, F. Rodriguez, G. Agarwal, S.M. Kirkpatrick, M.O. Stone, Prog. Org. Coat. 47 (2003) 249.

[65] C. Tamerler, S. Dincer, D. Heidel, M. Hadi Zareie, M. Sarikaya, Prog. Org. Coat. 47 (2003) 267.

[66] M. Wahl, K. Kröger, M. Lenz, Biofouling 12 (1998) 205

[67] A.R. Davis, N.M. Targett, O.J. McConnell, C.M. Young, in: P.J. Scheuer (Ed.), Bioorganic Marine Chemistry, vol. 3, Springer-Verlag, Berlin, 1989, p. 85.

[68] G.J. Bakus, M. Wright, A.K. Khan, B. Ormsby, D.A. Gulko, W. Licuanan, E. Carriazo, A. Ortiz, D.B. Chan, D. Lorenzana, M.P. Huxley, in: M.-F. Thompson, R. Nagabhushanam, R. Sarojini, M. Fingerman (Eds.), Recent Developments in Biofouling Control, A.A. Balkema, Rotterdam, 1994, p. 373.

[69] N. Fusetani, Nat. Prod. Rep. 21 (2004) 94.

[70] C. Hellio, C. Simon-Colin, A.S. Clare, E. Deslandes, Biofouling 20 (2004) 139.

[71] R. De Nys, P.D. Steinberg, P. Willemsen, S.A. Dworjanyn, C.L. Gabelish, R.J. King, Biofouling 8 (1995) 259.

[72] G.M. Nylund, H. Pavia, Mar. Biol. 143 (2003) 875.

[73] J.R. Pawlik, Chem. Rev. 93 (1993) 1911.

[74] R. de Nys, S.A. Dworjanyn, P.D. Steinberg, Mar. Ecol., Prog. Ser. 162 (1998) 79.

[75] R.P. Price, M. Patchan, A. Clare, D. Rittschof, J. Bonaventura, Biofouling 6 (1992) 207.

[76] M. Pérez, G. Blustein, M. García, B. del Amo, M. Stupak, Prog. Org. Coat. 55 (2006) 311.

[77] J.G. Burgess, K.G. Boyd, E. Armstrong, Z. Jiang, L. Yan, M. Berggren, U. May, T. Pisacane, Å. Granmo, D.R. Adams, Biofouling 19 (2003) 197 (Supplement).

[78] M. Sjögren, M. Dahlström, U. Göransson, P.R. Jonsson, L. Bohlin, Biofouling 20 (2004) 291.

[79] M.E. Stupak, M.T. García, M.C. Pérez, Int. Biodeterior. Biodegrad. 52 (2003) 49.

[80] C. Baum, W. Meyer, R. Stelzer, L.-G. Fleischer, D. Siebers, Mar. Biol. $140(2002) 653$.

[81] W. Meyer, U. Seegers, Mar. Biol. 144 (2004) 841.

[82] E. Roberts, Mar. Scientist 11 (2005) 28.

[83] M.L. Carman, T.G. Estes, A.W. Feinberg, J.F. Schumacher, W. Wilkerson, L.H. Wilson, M.E. Callow, J.A. Callow, A.B. Brennan, Biofouling $22(2006) 1$.

[84] A.V. Bers, M. Wahl, Biofouling 20 (2004) 43.

[85] A. Scardino, R. de Nys, O. Ison, W. O'Connor, P. Steinberg, Biofouling 19 (2003) 221 (Supplement).

[86] K.M. Berntsson, P.R. Jonsson, M. Lejhall, P. Gatenholm, J. Exp. Mar. Biol. Ecol. 251 (2000) 59. 
[87] M. Jelvestam, S. Edrud, S. Petronis, P. Gatenholm, Surf. Interface Anal. 35 (2003) 168

[88] L. Hoipkemeier-Wilson, J.F. Schumacher, M.L. Carman, A.L. Gibson, A.W. Feinberg, M.E. Callow, J.A. Finlay, J.A. Callow, A.B. Brennan, Biofouling 20 (1) (2004) 53.

[89] A.J. Scardino, R. de Nys, Biofouling 20 (2004) 249.

[90] J.L. Dalsin, B.-H. Hu, B.P. Lee, P.B. Messersmith, J. Am. Chem. Soc. 125 (2003) 4253

[91] A.L. Lewis, Colloids Surf., B Biointerfaces 18 (2000) 261.

[92] F. Navarro-Villoslada, G. Orellana, M.C. Moreno-Bondi, T. Vick, M. Driver, G. Hildebrand, K. Liefeith, Anal. Chem. 73 (2001) 5150

[93] Q. Zhao, Y. Liu, C. Wang, S. Wang, H. Müller-Steinhagen, Chem. Eng. Sci. 60 (2005) 4858

[94] W. Barthlott, C. Neinhuis, Planta 202 (1997) 1.

[95] J.F.V. Vincent, D.L. Mann, Philos. Trans. R. Soc. Lond., A 360 (2002) 159.

[96] T. Matsunaga, T.K. Lim, Electrochemistry 68 (11) (2000) 847.

[97] A.L. Phillippi, N.J. O’Connor, A.F. Lewis, Y.K. Kim, Aquaculture 195 (2001) 225.

[98] M.E. Pettitt, S.L. Henry, M.E. Callow, J.A. Callow, A.S. Clare, Biofouling 20 (2004) 299.
[99] T. Leya, A. Rother, T. Müller, G. Fuhr, M. Gropius, B. Watermann, in: J.A Lewis (Ed.), 10th International Congress on Marine Corrosion and Fouling, University of Melbourne, 1999: Additional Papers, 2001, p. 98, Report DSTO-GD-0287.

[100] J.D. Adkins, A.E. Mera, M.A. Roe-Short, G.T. Pawlikowski, R.F. Brady Jr., Prog. Org. Coat. 29 (1996) 1.

[101] P. Kingshott, H.J. Griesser, Curr. Opin. Solid State Mater. Sci. 4 (1999) 403.

[102] G.L. Kenausis, J. Vörös, D.L. Elbert, N. Huang, R. Hofer, L. Ruiz-Taylor, M. Textor, J.A. Hubbell, N.D. Spencer, J. Phys. Chem., B 104 (2000) 3298

[103] H. S. Preiser, A. Ticker, G. S. Bohlander, D. W. Taylor in: J. D. Costlow, R. C. Tipper (Eds.), Marine Biodeterioration: An Interdisciplinary Study, Naval Institute Press, MD, USA, London E. and F. N. SPON, 1984 p.223.

[104] L.S. Shtykova, D. Ostrovskii, P. Handa, K. Holmberg, M. Nydén, Prog. Org. Coat. 51 (2004) 125.

[105] A. Nishida, K. Ohkawa, I. Ueda, H. Yamamoto, Biomol. Eng. 20 (2003) 381.

[106] A. Matthews, The Donald Julius Groen Lecture 2005, Institution of Mechanical Engineers Tribology Groups, I Mech E, London, Dec 2005. 